\title{
Significance of nanophytoplankton photosynthesis and primary production in a coastal upwelling system (Ría de Vigo, NW Spain)
}

\author{
G. H. Tilstone ${ }^{1, *}$, F. G. Figueiras ${ }^{1}$, E. G. Fermín ${ }^{2}$, B. Arbones ${ }^{1}$ \\ ${ }^{1}$ Instituto de Investigacións Mariñas, C.S.I.C., Eduardo Cabello 6, E-36208 Vigo, Spain \\ ${ }^{2}$ Escuela de Ciencias Aplícadas del Mar, Universidad de Oriente, Boca de Río, Isla Margarita, Venezuela
}

\begin{abstract}
The Rías Baixas are reported to have the highest primary production along the NW coast of Spain due to the influence of upwelling, which occurs trom April to October. Samples were taken over 2 wk periods at a single station in the Ria de Vigo during spring, summer and autumn 1993 to study the variation in the phytoplankton photosynthetic parameters (light limited slope, $\alpha^{B}$ and light saturated chlorophyll specific rate, $P_{m}^{B}$ ) and daily primary production in relation to phytoplankton size class, species and hydrographic parameters. The range in primary production for the Ría was 65 to $3689 \mathrm{mg} \mathrm{C} \mathrm{m} \mathrm{m}^{-2} \mathrm{~d}^{-1}$ for total phytoplankton, 65 to $2833 \mathrm{mg} \mathrm{C} \mathrm{m}^{-2} \mathrm{~d}^{-1}$ for net phytoplankton and 0 to $1650 \mathrm{mg} \mathrm{C} \mathrm{m}{ }^{-2} \mathrm{~d}^{-1}$ for nanophytoplankton. The data suggest that most of the variation in primary production in the Ría during the upwelling season was due to nanophytoplankton. Upwelling/downwelling cycles in the Ría therefore give rise to a larger variation in energy transfer through the microbial loop than through the classic, short, food chain. This is caused mainly by increases in nanophytoplankton $\alpha^{B}$ coupled with high $\mathrm{NO}_{3}$ due to upwelling events. The data also suggest that there are 3 principal factors that give high primary production in the Ría. Periodic relaxation and stratification events linked to water column heating during upwelling/downwelling cycles coincided with periods of high productivity. Size class also influences the primary production; net phytoplankton had significantly higher primary production during the upwelling season than the nanophytoplankton and was responsible for $66 \%$ of the mean primary production. Species differences affected the primary production in the Ría; highest values coincided with blooms of Chaetoceros spp. and the lowest with dinoflagellate blooms of Gymnodinium catenatum.
\end{abstract}

KEY WORDS: Net phytoplankton - Nanophytoplankton P Photosynthesis - Primary production Stratification - Upwelling/downwelling · Microbial loop $\cdot$ Ría de Vigo

\section{INTRODUCTION}

Variations in photosynthesis and primary production in the ocean are complex and have been attributed to factors such as temperature (Platt \& Jassby 1976. Harding et al. 1986), available nitrogen (Harrison \& Platt 1980, Platt et al. 1992, Kyewalyanga et al. 1998), stratification (Gallegos et al. 1983), turbulence (Lewis et al. 1984), light intensity and quality in the water column (Falkowski 1981, Côté \& Platt 1984, Kyewalyanga et al. 1998), size and diversity of phytoplankton species

\footnotetext{
•E-mail: gtilston@iim.csic.es
}

(Malone 1980, Côté \& Platt 1984, Gallegos 1992) as well as the physiological state of the phytoplankton population (Platt et al. 1993). More than 1 variable may be acting on photosynthetic parameters at any one time and it is often difficult to discern the effect of one factor from another (e.g. Lohrenz et al. 1994). Variations in primary production have therefore been related to the physical structure of the water column, which influences a number of co-varying factors (Mann 1993). In upwelling zones, the variance in primary production is dependent on the strength of vertical advection and the duration of stratification (Huntsman \& Barber 1977, Minas et al. 1982). Generally, high and continual vertical advection reduces primary pro- 
duction due to high water column mixing and the shifting of phytoplankton offshore (Marra 1980). Primary production increases during weak upwelling since phytoplankton has a longer residence time in optimal light and nutrient conditions (Huntsman \& Barber 1977, Small \& Menzies 1981). However, there is still some debate about the role of stratification in primary production. Légendre (1981) suggested that destabilisation/stabilisation events are necessary to force high primary production, whereas recent models have suggested that stratification reduces production (Prestidge \& Taylor 1995, Ménesguen \& Hoch 1997). It is evident that the duration of stratification is critical in increasing or decreasing primary production. Periods of long stratification can result in lower primary production due to nutrient consumption and limitation and to the sedimentation of phytoplankton from the photic zone (Cushing 1989). The alteration between high winds followed by periods of stratification and water column heating have been reported to yield high primary production (Brown \& Field 1986, Peterson et al. 1988, González-Rodríguez et al. 1992), as long as factors such as light and nutrients are not limiting (Légendre 1981).

Photosynthesis and primary production in the sea are influenced by phytoplankton size class (Banse 1976, Malone \& Neale 1981, Geider et al. 1986, Platt et al. 1993, Raven 1995) which is related to the physical structure of the water column (Semina 1968) and the associated light and nutrient regimes (Kiørboe et al. 1990, Hood et al. 1992). The importance of size class and production in marine systems has been summarised by Cushing (1989) and Azam et al. (1983). These authors make the distinction between small cells $(<5 \mu \mathrm{m})$ which are mainly grazed by protozoa and ciliates and therefore pass through the microbial loop, and larger cells (>5 $\mu \mathrm{m}$ ) which are fed directly into the classic, short, food chain. The microbial loop is longer and more inefficient in energy transfer than the classic food chain but is important in the rapid recycling of nutrients above the thermocline where $50 \%$ of the carbon fixed by phytoplankton may be recirculated (Azam 1998). The microbial loop is particularly important in oligotrophic and stratified waters, where high division rates result in high exudate output (Cushing 1989). The classic, short, food chain is typical in areas of high turbulence such as upwelling zones (Ryther 1969) and upwelling fronts (Yoder et al. 1994), where water movement aids flotation and nutrient uptake (Kiørboe 1993).

Upwelling occurs along the NW Atlantic coast of Spain from April to October (McClain et al. 1986) and enhances biological productivity (Tenore et al. 1995). The Rias Baixas are 4 flooded tectonic valleys located on the NW coast of Spain. The Rías are reported to be the most productive zones in this region due to nutrient enrichment through local circulation (Álvarez-Salgado et al. 1996), terrestrial run off (Nogueira et al. 1997) and upwelling (Álvarez-Salgado et al. 1993). The highest primary production in one of the Rías (Ría de Vigo) has been recorded during upwelling events in July and August (Fraga 1976), when diatoms dominate the water column (Moncoiffe et al. 1993). Prego (1993) used a box model of organic and inorganic carbon fluxes to derive net primary production in the Ría and found that upwelling events from April to October doubled primary production. In the coastal waters of NW Spain the highest proportion of primary production is due to the net phytoplankton (Bode et al. 1994). To date, no photosynthesis-irradiance (P-E) data and comparatively little size-fractionated primary production data for phytoplankton have been collected from the Rías. In addition, very little research has been done on the significance of primary production for different size fractions and their relevance on food webs in this region, despite the fact that the Rías have one of the most productive shellfish cultures in Europe. The variation in photosynthetic parameters during the upwelling season and the effect of upwelling/downwelling cycles on primary production in the Rías also remains unknown. There is an obvious need for more data from this region on the seasonal distribution of $\mathrm{P}$ E parameters and the factors that control these parameters to improve the large scale computation of primary productivity (Sathyendranath et al. 1995).

This research was aimed at studying the variation in the P-E parameters (light limited slope, $\alpha^{B}$ and light saturated chlorophyll specific rate, $P_{m}^{B}$ ) and daily primary production for total, net and nanophytoplankton in the Ría de Vigo during the upwelling season. Spatial and temporal variations in these parameters were related to hydrographic variables. The effect of relaxation/stratification events during upwelling/downwelling cycles on phytoplankton photosynthesis and primary production was also studied.

\section{MATERIAL AND METHODS}

Hydrography. A single sampling station (Fig. 1) in the Ría de Vigo was sampled over 2 wk periods in spring, summer and autumn 1993. The station was initially surveyed using a conductivity-temperaturedepth sampler (CTD Sea Bird 25) fitted with a 'Sea Tech' fluorometer. Using the fluorescence profiles obtained from a single CTD cast, maximum fluorescence peaks were used to determine sampling depths for a more detailed analysis of the biological characteristics of the Ría. Seawater samples were then collected at 5 depths in the water column, with 2 or 3 samples 
located near to the fluorescence maximum, using 5 l Niskin bottles fitted with reversing thermometers. Aliquots were taken from the Niskin bottles and frozen immediately for the analysis of nutrients in the laboratory using a Technicon AAII SFA auto analyser. The reduction method to nitrites in a $\mathrm{Cd}-\mathrm{Cu}$ column (Mouriño \& Fraga 1985) was used to determine nitrate. A sub-sample of $100 \mathrm{ml}$ of seawater from each sample was filtered through a $2.5 \mathrm{~cm}$ Whatman GF/F filter and chlorophyll a (chl) values were then determined by fluorometry using a Turner fluorometer Model 10000 R (Yentsch \& Menzel 1963). Conductivity was measured using an autosal $8400 \mathrm{~A}$ salinometer calibrated with standard seawater and salinity was then calculated using the UNESCO (1983) equation. Density excess $\left(\mathrm{kg} \mathrm{m}^{-3}\right.$ minus $\left.1000, \sigma_{1}\right)$ was also calculated using the UNESCO (1985) equation. Ekman transport $\left(Q_{x}\right.$, transport perpendicular to coast related to upwelling intensity) was obtained from geostrophic wind calculations (Bakun 1973) and taken from Nogueira et al. (1997).

Size-fractionated variables. Three depths were sampled within the photic layer: surface, depth of the chl maximum, and depth of $1 \%$ of the incident irradiance at the sea surface. Nanophytoplankton was separated from the total phytoplankton by gentle reverse filtration through a $20 \mu \mathrm{m}$ nylon net. Samples of nano and total phytoplankton were taken for phytoplankton counts, chlorophyll measurements, and estimates of photosynthetic parameters.

Phytoplankton identification and biovolume. Samples of each fraction were preserved in Lugol's iodine and sedimented in $50 \mathrm{ml}$ composite sedimentation chambers. Diatoms, dinoflagellates, flagellates larger than $20 \mu \mathrm{m}$ and ciliates (oligotrichous and peritrichous) were identified and counted to the species level where possible, using an inverted microscope (Uter-

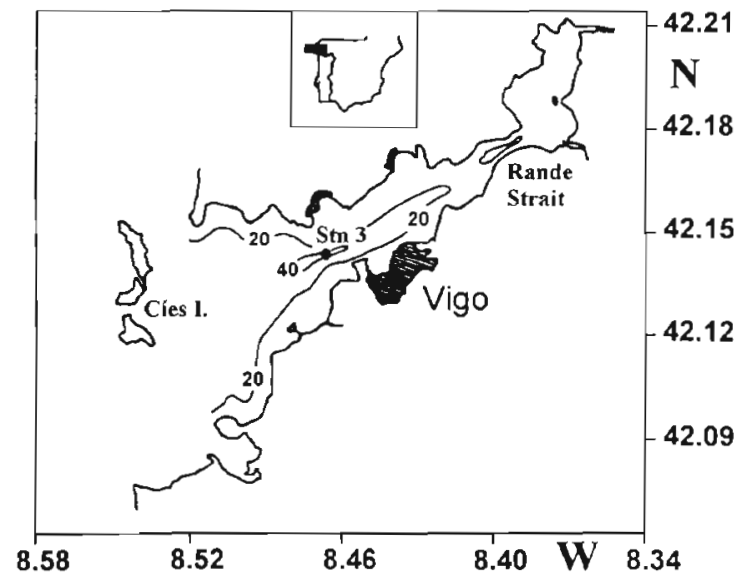

Fig. 1. The study area (northwest corner of Iberian Peninsula) and a single sampling station (Stn 3) in the Ría de Vigo möhl 1958). Small species were counted in single transects at $\times 250$ and $\times 400$ and a scan of the whole slide at $\times 100$ was used for larger species. The dimensions of each of the species identified were measured and cell volumes were determined by approximation to the nearest geometric shape (Edler 1979). In addition to Lugol's preserved samples, $10 \mathrm{ml}$ of each fraction was fixed in formaldehyde ( $4 \%$ final conc.) and placed in the dark for $10 \mathrm{~min}$ at $5^{\circ} \mathrm{C}$. The samples were then filtered through $0.2 \mathrm{~mm}$ Millipore black filters at a pressure of $<50 \mathrm{~mm}$ of $\mathrm{Hg}$ and stored at $-20^{\circ} \mathrm{C}$ in the dark until further analysis. The filters were then immersed in low flourescence immersion oil and examined at $\times 1000$ using a Nikon microscope fitted with an epiflourescence lamp and filter adapted to an excitation of 425 to $490 \mathrm{~nm}$. The cyanobacteria were distinguished by yellow colouration, the autotrophic picoflagellates by yellow-orange and the nanoflagellates by a red colour. Cell volumes were calculated using a spherical model.

Photosynthesis-irradiance relationships (P-E curves) of total and nanophytoplankton fractions. From the 3 depths, 14 sub-samples of each phytoplankton fraction (total and nanophytoplankton) were pipetted into $75 \mathrm{ml}$ Corning culture vessels and inoculated with 1.85 $\times 10^{5} \mathrm{~Bq}(5 \mu \mathrm{Ci}) \mathrm{NaH}^{14} \mathrm{CO}_{3}$. They were then placed in linear incubators and maintained at in situ temperature using a water bath and pump. Osram tungsten halogen lamps with dichroic reflector and a Deco glass cover $(50 \mathrm{~W}, 12 \mathrm{~V})$ illuminated the front side of the incubators and irradiance in each cell was measured using a Li-Cor cosine sensor LI-190SA. The fourteenth bottle in each incubator was used as a control and was covered with aluminium foil to measure carbon fixation in the dark. After 2 h of incubation, the suspended material was filtered through $25 \mathrm{~mm}$ Whatman GF/F glass fibre filters at a pressure of $<20 \mathrm{~cm} \mathrm{Hg}$ and the filters were then exposed to $\mathrm{HCl}$ vapours for $12 \mathrm{~h}$. Disintegrations per minute (DPM) were determined using a liquid scintillation counter with quench correction by the external standard method and a stored quench curve of known activity. The P-E data were fitted using the model of Webb et al. (1974) since photoinhibition was not observed:

$$
P_{Z}^{B}=P_{m}^{B}\left[1-\exp \left(-\alpha^{B} E / P_{m}^{B}\right)\right]
$$

where $P_{m}^{B}$ is the light saturated chl-specific rate of photosynthesis, $\mathrm{mg} \mathrm{C}(\mathrm{mg} \mathrm{chl})^{-1} \mathrm{~h}^{-1} ; \alpha^{B}$ the initial slope of the P-E curve, $\mathrm{mg} \mathrm{C}(\mathrm{mg} \mathrm{chl})^{-1} \mathrm{~h}^{-1}\left(\mu \mathrm{mol} \mathrm{m} \mathrm{m}^{-2} \mathrm{~s}^{-1}\right)^{-1}$; and $E\left(\mu \mathrm{mol} \mathrm{m} \mathrm{m}^{-2} \mathrm{~s}^{-1}\right)$ the incident light in each bottle of the incubator. The mean analytical error in calculating $P_{m}^{B}$ is $5 \%$ and $15 \%$ for $\alpha^{B}$.

Photosynthetic parameters of net phytoplankton. At saturated irradiance, the chl-specific rate of photosynthesis for net phytoplankton can be derived from: 


$$
P_{m>20 \mu m}^{B}=\frac{P_{m \text { tot }}^{B} \cdot \operatorname{chl}_{\text {tot }}-P_{m<20 \mu m}^{B} \cdot \operatorname{chl}_{20 \mu \mathrm{m}}}{\mathrm{chl}_{\text {tot }}-\mathrm{chl}_{20 \mu \mathrm{m}}}
$$

At limited irradiance, carbon fixation of each phytoplankton fraction is a linear function of the respective chl concentration, $\alpha^{B}$ and irradiance. Therefore, the net phytoplankton carbon fixation can be derived from the difference between total and nanophytoplankton carbon fixation as follows:

$$
\begin{aligned}
& \operatorname{chl}_{>20 \mu \mathrm{m}} \cdot \alpha_{B>20 \mu \mathrm{m}} \cdot E= \\
&\left(\mathrm{chl}_{\mathrm{tot}} \cdot \alpha_{\mathrm{lot}}^{B} \cdot E\right)-\left(\operatorname{chl}_{<20 \mu \mathrm{m}} \cdot \alpha_{<20 \mu \mathrm{m}}^{B} \cdot E\right)
\end{aligned}
$$

The light-limited slope of the net phytoplankton can be deduced from the transposition of Eq. (3):

$$
\alpha_{>20 \mu \mathrm{m}}^{B}=\frac{\mathrm{chl}_{\mathrm{tot}} \cdot \alpha_{\mathrm{tot}}^{B}-\mathrm{chl}_{<20 \mu \mathrm{m}} \cdot \alpha_{<20 \mu \mathrm{m}}^{B}}{\mathrm{chl}_{\mathrm{tot}}-\mathrm{chl}_{<2 \mathrm{\mu m}}}
$$

Systematic errors in calculating $P_{m>20 \mu m}^{B}$ and $\alpha_{>20 \mu m}^{B}$ were estimated using the mean analytical error in determining $\alpha^{B}, P_{m}^{B}$ and chl $(=5 \%)$ for total and nanophytoplankton and the actual minimum and maximum values in all combinations of the terms used in Eqs. (2) $\&$ (4). Unreal scenarios such as maximum $P_{\text {mtot }}^{B} \cdot \mathrm{chl}_{\mathrm{tol}}$ and minimum $\mathrm{chl}_{\mathrm{lot}}$ maximum $\alpha_{\mathrm{tot}}^{B} \cdot \mathrm{chl}_{\mathrm{tot}}$ and minimum $\mathrm{chl}_{\text {tot }}$ and minimum $\alpha_{\text {tot }}^{B} \cdot \mathrm{chl}_{\text {tot }}$ and maximum chl ${ }_{\text {tot }}$ as well as impossible situations such as nanophytoplankton production and/or chl higher than those for total phytoplankton were not considered in calculating the mean error (see Table 1). The total mean error in calculating $P_{m>20 \mu m}^{B}$ was 11 and $17.5 \%$ for $\alpha_{>20 \mu m}^{B}$.
Photosynthetic active radiation and primary production. The penetration of photosynthetic active radiation (PAR 400-700 nm) in the water column was determined at intervals of $2 \mathrm{~m}$ using a Li-Cor spherical quantum sensor LI-193SA (scalar measurement). Incident sea surface PAR $\left(E_{0}+\right)$ was also determined (cosine measurement) simultaneously using a Li-Cor cosine sensor (LI-190SA). Unclerwater PAR at $0 \mathrm{~m}$ depth $\left(E_{0^{-}}\right)$were calculated by adjusting the PAR profile to the equation of light attenuation coefficient $(k)$ with depth $(z)$ :

$$
E_{z}=E_{0-} \cdot e^{-k \cdot z}
$$

The light transmittance at the air-sea interface was calculated by dividing $E_{0}-$ by $E_{0}+$. The daily solar radiation (PAR) was measured at 1 min intervals using a LI190SA placed on the terrace roof of the IIM, CSIC, Marine Institute, which is located close to the sampling station on the south coast of the Ría de Vigo. Readings were integrated at hourly intervals during the sampling days.

The daily primary production $\left(P_{z}, \mathrm{mg} \mathrm{C} \mathrm{m}^{-3} \mathrm{~d}^{-1}\right)$ at each sampled depth $(z)$ and for each phytoplankton fraction was estimated using the formula:

$$
P_{z}=\operatorname{chl} \cdot P_{m}^{B} \int_{t=0}^{24}\left[1-\exp \left(-\alpha^{B} \quad E_{z}(t) / P_{m}^{B}\right)\right] \mathrm{d} t
$$

and water column primary production was integrated down to the bottom of the photic layer.

Statistical analysis. A Kolmogrov-Smirnov with Lil-

\begin{tabular}{|c|c|c|c|}
\hline Variables $P_{m}^{B}$ and chl $a$ & $\begin{array}{l}P_{m>20}^{B}, \mathrm{~m} \\
(\mathrm{mean} \%) \\
\text { Range \% }\end{array}$ & Variables $\alpha^{B}$ and chl $a$ & $\begin{array}{c}\alpha_{>}^{B}>2 \text { pim } \\
(\text { mean } \%) \\
\text { Range \% }\end{array}$ \\
\hline 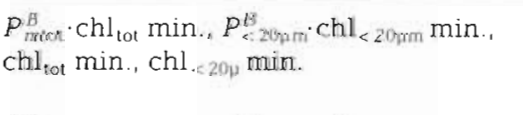 & $\begin{array}{r}(15) \\
4 \text { to } 32 \\
-6 \text { to }-25\end{array}$ & $\begin{array}{l}\alpha_{\text {tot }}^{B} \cdot \operatorname{chl}_{\text {tot }} \max , \alpha_{<20 \mu \mathrm{mi}}^{B} \cdot \mathrm{chl}_{<20 \mu \mathrm{m}} \min . \\
\mathrm{chl}_{\text {tot }} \max , \operatorname{chl}_{<20 \mu \mathrm{m}} \max .\end{array}$ & $\begin{array}{r}(16) \\
7 \text { to } 24 \\
-8 \text { to }-21\end{array}$ \\
\hline $\begin{array}{l}P_{\text {mtot }}^{B} \cdot \operatorname{chl}_{\text {tot }} \max , P_{<20 \mu \mathrm{mm}}^{B} \cdot \mathrm{chl}_{<20 \mu \mathrm{m}} \min \\
\mathrm{chl}_{\text {tot }} \max , \operatorname{chl}_{<20 \mu \mathrm{m}} \max .\end{array}$ & $\begin{array}{r}(8) \\
1 \text { to } 14 \\
-1 \text { to }-12\end{array}$ & $\begin{array}{l}\alpha_{\text {tof }}^{B} \cdot \operatorname{chl}_{\text {tot }} \max ., \alpha_{<20 \mu m}^{B} \cdot \operatorname{chl}_{<20 \mu m} \text { min.., } \\
\text { chl }_{\text {tot }} \max ., \operatorname{chl}_{<20 \mu m} \text { min. }\end{array}$ & $\begin{array}{r}(16) \\
9 \text { to } 21 \\
-10 \text { to }-19\end{array}$ \\
\hline $\begin{array}{l}P_{\text {moto }}^{B} \cdot \mathrm{chl}_{\text {tot }} \max ., P_{<20 \mu \mathrm{mm}}^{B} \cdot \mathrm{chl}_{<20 \mu \mathrm{m}} \mathrm{min} . \\
\mathrm{chl}_{\text {tot }} \max , \mathrm{chl}_{<20 \mu \mathrm{m}} \mathrm{min} .\end{array}$ & $\begin{array}{r}(7) \\
0 \text { to } 11 \\
-0 \text { to }-10\end{array}$ & 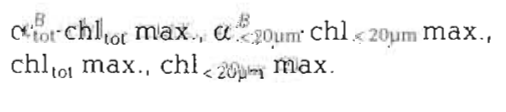 & $\begin{array}{r}(19) \\
7 \text { to } 31 \\
-8 \text { to }-27\end{array}$ \\
\hline $\begin{array}{l}P_{\text {mtot }}^{B} \cdot \operatorname{chI}_{\text {to: }} \max , P_{<20 \mu \mathrm{m}}^{B} \cdot \mathrm{chl}_{<20 \mu \mathrm{m}} \max . \\
\mathrm{chl}_{\text {tot }} \max , \mathrm{chl}_{<20 \mu \mathrm{m}} \max .\end{array}$ & $\begin{array}{r}(12) \\
3 \text { to } 23 \\
-2 \text { to }-20\end{array}$ & $\begin{array}{l}\alpha_{\text {tot }}^{B} \cdot \operatorname{chl}_{\text {tol }} \max , \alpha_{<201 \mu \mathrm{sin}}^{B} \cdot \operatorname{chl}_{<20 \mu \mathrm{m}} \max . \\
\operatorname{chl}_{\text {tot }} \max ., \operatorname{chl}_{<2 \mathrm{OHm}} \min .\end{array}$ & $\begin{array}{r}(19) \\
9 \text { to } 28 \\
-10 \text { to }-25\end{array}$ \\
\hline $\begin{array}{l}P_{\text {mtot }}^{B} \cdot \operatorname{chl}_{\text {tot }} \max , P_{<20 \mu \mathrm{m}}^{B} \cdot \mathrm{chl}_{<20 \mu \mathrm{m}} \max ., \\
\text { chl }_{\text {tot }} \max ., \mathrm{chl}_{<20 \mu \mathrm{m}} \mathrm{min} .\end{array}$ & $\begin{array}{r}(12) \\
1 \text { to } 20 \\
-1 \text { to }-18\end{array}$ & & \\
\hline Total mean error & $11 \%$ & Total mean error & $17.5 \%$ \\
\hline
\end{tabular}
liefors test was employed to check if the distribution of each variable was normal. The distributions of the pho-

Table 1. Systematic errors in calculating $P_{m>20 \mu m}^{B}$ and $\alpha_{>20 \mu m}^{B}$ using the minimum and maximum values of $P_{m}^{B}$, $\alpha^{B}$ and chl of total and nanophytoplankton fractions in all possible combinations. Negative errors indicate underestimation, positive errors indicate overestimation. Unrealistic and impossible situations were not included in the analysis - see 'Methods' for more details 
tosynthetic variables were found to be non-normal; $\alpha^{B}$ and $P_{m}^{B}$ were $\log$ transformed until no significant differences were found between the expected and the observed distributions for both tests. The seasonal variability of each parameter was tested separately for total, net and nanophytoplankton using 1 -way ANOVA. Differences between the total, net and nanophytoplankton were also tested using 1-way ANOVA. Principal component analyses (PCA) based on correlation matrix from the spring, summer and autumn sampling periods were employed to assess the variation in $\alpha^{B}, P_{m}^{B}$ and $P_{z}$ for each phytoplankton fraction in relation to the environmental variables. All parameters were transformed as far as possible until no significant differences were found between the expected and the observed distributions for the Kolmogrov-Smirnov with Lilliefors test.

\section{RESULTS}

\section{Hydrography}

The April 1993 sampling period represents a sequence of upwelling/downwelling/upwelling. The main hydrographic changes and associated wind directions and velocities are summarised in Table 2. From the 14 to 16 April 1993 the wind direction was from the northwest, which initiated upwelling, characterised by a decrease in temperature and increase in nitrate throughout the water column (Fig. 2). The upwelling of sub-surface coastal water established a positive estuarine circulation; sub-surface water moved into the Ría and Ría surface water moved towards the ocean (see salinity and density data, Table 2, and previous studies, e.g. Fraga \& Margalef 1979, Figueiras et al. 1994). Downwelling occurred from 19 to 23 April and caused an intrusion of surface coastal water into the Ría (see salinity Table 2 and temperature Fig. 2) and an accumulation of chl in the surface layers (>8 $\mathrm{mg} \mathrm{m}^{-3}$, Fig. 2). Nitrate was low at the surface during upwelling and downwelling, which indicated consumption by phytoplankton (Fig. 2; see also Figueiras \& Pazos 1991). Upwelling was re-initiated by northwesterly winds by 27 April (Table 2), which coincided with a decrease in chl and an increase in nitrate (Fig. 2). Irradiance levels $\left(E_{z}\right)$ were highest at the beginning of the sampling period, reaching values of $600\left(\mathrm{~mol} \mathrm{~m}^{-2} \mathrm{~s}^{-1}\right.$ at the surface. $E_{\mathrm{z}}$ was reduced on the

Table 2. Summary of wind direction and velocity, salinity and density during different hydrographic periods in the Ría de Vigo. Surface, mid-and bottom layers correspond to primary production sampling depths

\begin{tabular}{|c|c|c|c|c|c|c|}
\hline Period & Wind direction & $\begin{array}{l}\text { Mean wind } \\
\text { velocity }\left(\mathrm{m} \mathrm{s}^{-1}\right)\end{array}$ & $\begin{array}{l}\text { Hydrographic } \\
\text { conditions }\end{array}$ & Depth & $\begin{array}{l}\text { Salinity } \\
\text { (S) }\end{array}$ & $\begin{array}{l}\text { Density } \\
\qquad\left(\sigma_{1}\right)\end{array}$ \\
\hline \multicolumn{7}{|l|}{ Spring } \\
\hline $14-16 \mathrm{Apr}$ & NW & 6.44 & Upwelling & $\begin{array}{l}\text { Surface } \\
\text { Mid-layer } \\
\text { Bottom }\end{array}$ & $\begin{array}{l}34.49-35.40 \\
35.24-35.60 \\
35.33-35.78\end{array}$ & $\begin{array}{l}25.71-26.42 \\
26.17-26.63 \\
26.38-26.86\end{array}$ \\
\hline 19-23 Apr & SW & 6.50 & Downwelling & $\begin{array}{l}\text { Surface } \\
\text { Mid-layer } \\
\text { Bottom }\end{array}$ & $\begin{array}{l}35.27-35.09 \\
35.68-35.52 \\
32.85-35.72\end{array}$ & $\begin{array}{l}26.29-26.17 \\
26.71-26.25 \\
27.00-26.72\end{array}$ \\
\hline $27 \mathrm{Apr}$ & NW & 9.30 & Upwelling & $\begin{array}{l}\text { Surface } \\
\text { Mid-layer } \\
\text { Bottom }\end{array}$ & $\begin{array}{l}34.08 \\
35.35 \\
35.53\end{array}$ & $\begin{array}{l}25.32 \\
26.34 \\
26.56\end{array}$ \\
\hline $\begin{array}{l}\text { Summer } \\
5-7 \mathrm{Jul}\end{array}$ & $N E$ & 10.91 & Upwelling & $\begin{array}{l}\text { Surface } \\
\text { Mid-layer } \\
\text { Bottom }\end{array}$ & $\begin{array}{l}35.38-35.73 \\
35.79-35.83 \\
35.87-35.81\end{array}$ & $\begin{array}{l}25.84-26.47 \\
26.72-26.86 \\
26.91-27.04\end{array}$ \\
\hline $9-16 \mathrm{Jul}$ & NW & 7.33 & Stratification & $\begin{array}{l}\text { Surface } \\
\text { Mid-layer } \\
\text { Bottom }\end{array}$ & $\begin{array}{c}35.75-35.58 \\
35.78-35.85 \\
35.84\end{array}$ & $\begin{array}{c}26.09-25.69 \\
26.40-26.91 \\
27.02\end{array}$ \\
\hline $\begin{array}{l}\text { Autumn } \\
27 \text { Sep }\end{array}$ & NE & 4.71 & Relaxation & $\begin{array}{l}\text { Surface } \\
\text { Mid-layer } \\
\text { Bottom }\end{array}$ & $\begin{array}{l}34.98 \\
35.48 \\
35.83\end{array}$ & $\begin{array}{l}25.55 \\
26.04 \\
26.80\end{array}$ \\
\hline $29 \mathrm{Sep}-4 \mathrm{Oct}$ & SW & 15.05 & Downwelling & $\begin{array}{l}\text { Surface } \\
\text { Mid-layer } \\
\text { Bottom }\end{array}$ & $\begin{array}{l}35.12-35.14 \\
35.42-35.31 \\
35.72-35.34\end{array}$ & $\begin{array}{l}25.94-25.85 \\
26.02-26.29 \\
26.51-26.02\end{array}$ \\
\hline $6-8 \mathrm{Oct}$ & NW & 15.29 & Upwelling & $\begin{array}{l}\text { Surface } \\
\text { Mid-layer } \\
\text { Bottom }\end{array}$ & $\begin{array}{l}34.93-33.71 \\
35.03-35.10 \\
35.57-35.61\end{array}$ & $\begin{array}{l}25.76-24.86 \\
25.81-26.03 \\
26.47-26.58\end{array}$ \\
\hline
\end{tabular}



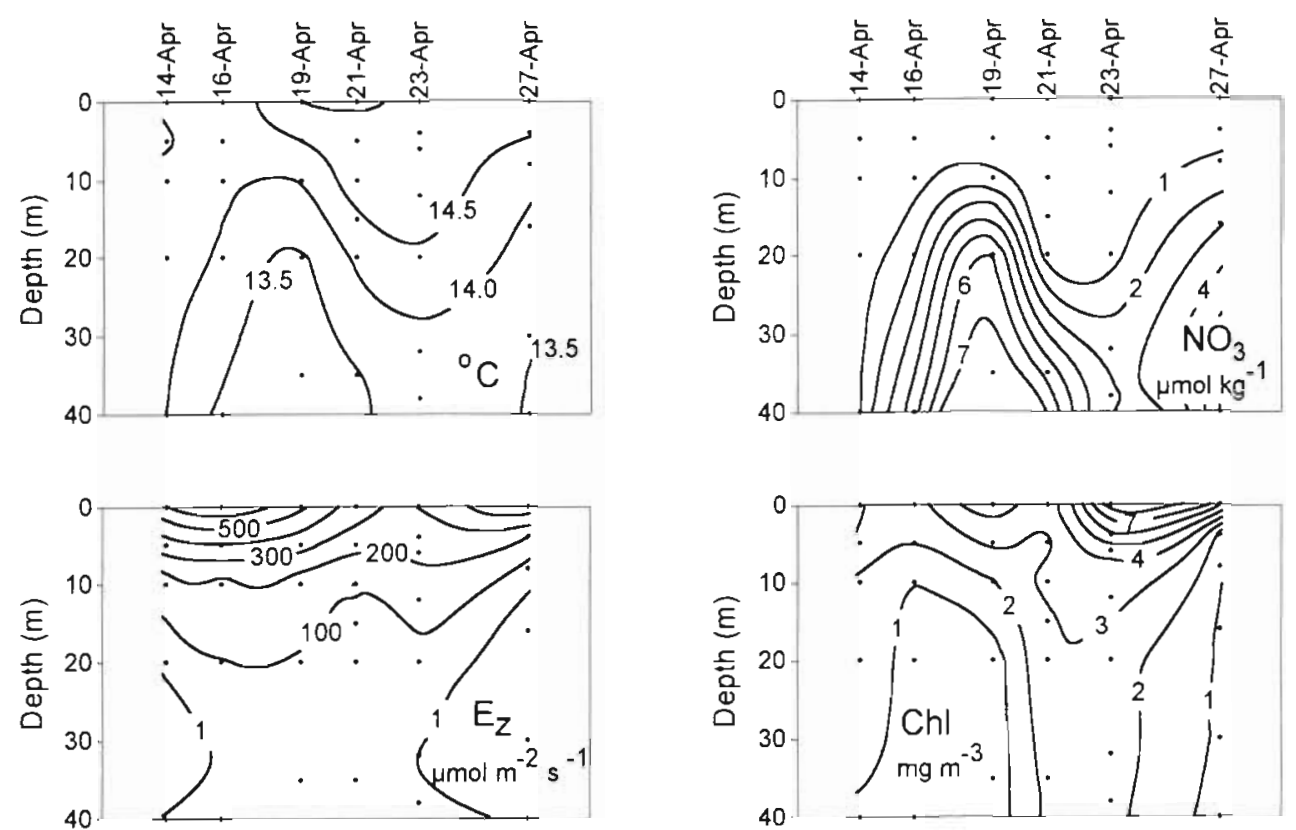

Fig. 2. Temperature $\left({ }^{\circ} \mathrm{C}\right)$, nitrate $\left(\mu \mathrm{mol} \mathrm{kg}{ }^{-1}\right)$, mean irradiance levels $\left(E_{z}\right)$ over $3 \mathrm{~d}$ (sampling day plus $2 \mathrm{~d}$ before; $\left.\mu \mathrm{mol} \mathrm{m}^{-2} \mathrm{~s}^{-1}\right)$ and chlorophyll a $\left(\mathrm{chl}_{i} \mathrm{mg} \mathrm{m}^{-3}\right)$ distributions in the Ría de Vigo from 14 to 27 April 1993
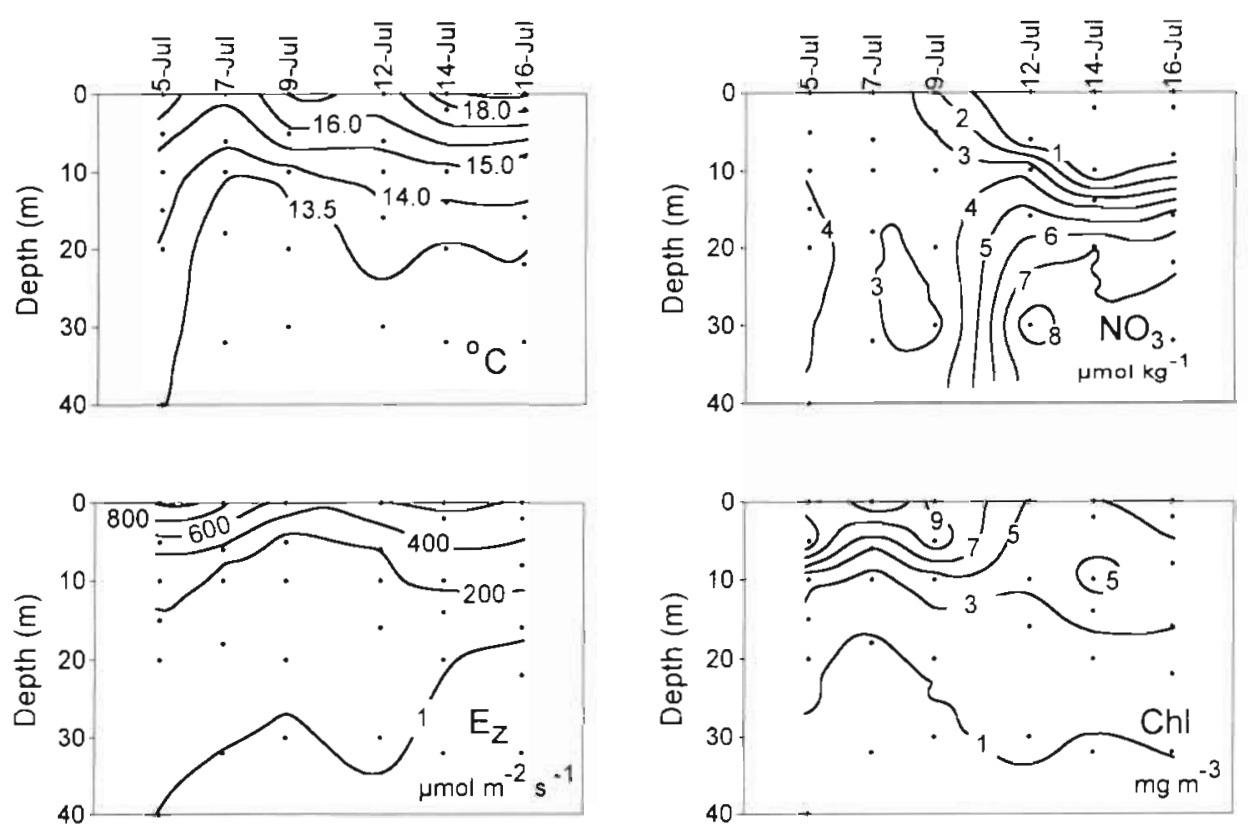

Fig. 3. Temperature $\left({ }^{\circ} \mathrm{C}\right)$, nitrate $\left(\mu \mathrm{mol} \mathrm{kg}{ }^{-1}\right)$, mean irradiance levels $\left(E_{z}\right)$ over $3 \mathrm{~d}$ (sampling day plus $2 \mathrm{~d}$ before; $\left.\mu \mathrm{mol} \mathrm{m} \mathrm{m}^{-2} \mathrm{~s}^{-1}\right)$ and chlorophyll a $\left(\mathrm{chl}_{;} \mathrm{mg} \mathrm{m}^{-3}\right)$ distributions in the Ría de Vigo from 5 to 16 July 1993

4th sampling day (Fig, 2), which was associated with moderate cloud cover and southwesterly winds from 19 April until 23 April.

The sampling period from 5 to 16 July represents an upwelling/relaxation/stratification sequence. The wind was predominantly from the northeast from 5 to 7 July 1993, which resulted in upwelling (Table 2, Fig. 3) and chl and nitrate levels were high during the first sampling days (Fig. 3). The water column became stratified from 9 to 16 July, with little change in temperature, 

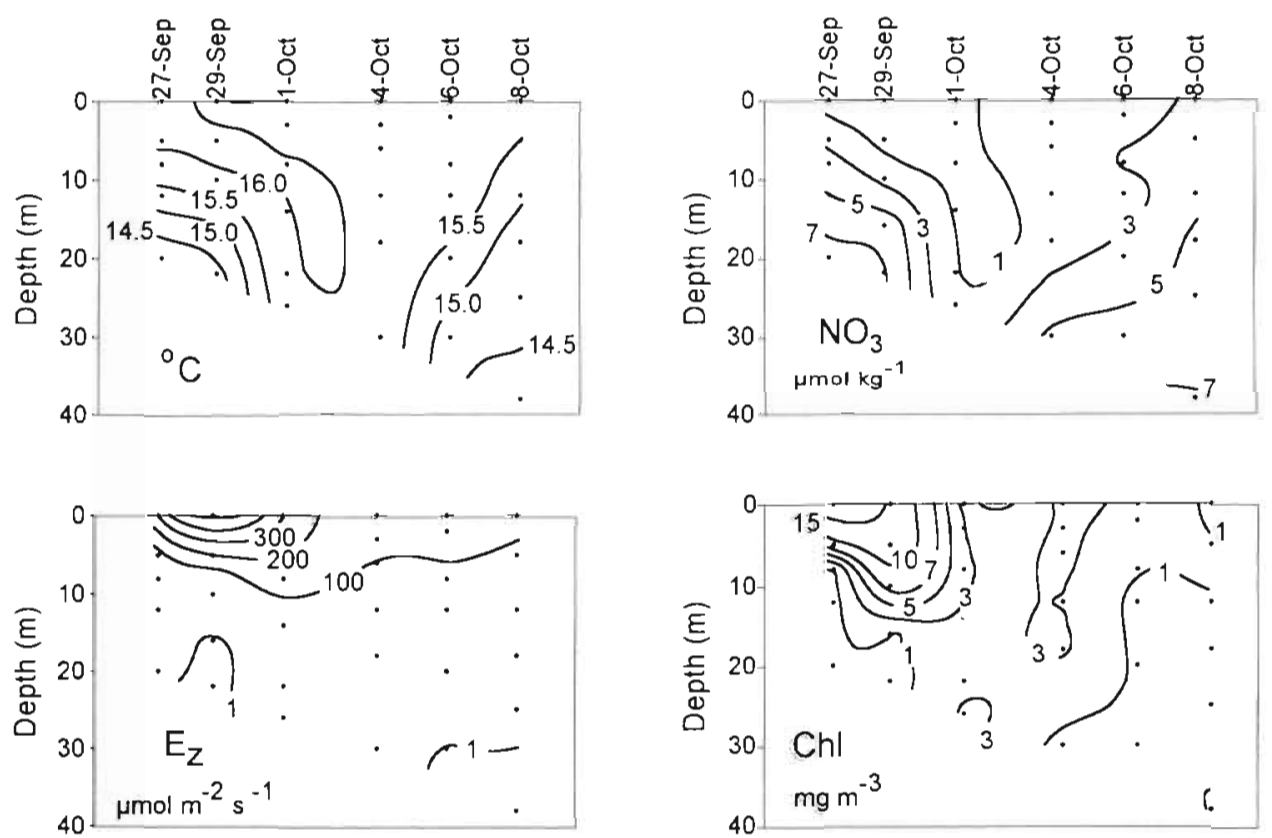

Fig. 4. Temperature $\left({ }^{\circ} \mathrm{C}\right)$, nitrate $\left(\mu \mathrm{mol} \mathrm{kg} \mathrm{kg}^{-1}\right)$, mean irradiance levels $\left(E_{z}\right)$ over $3 \mathrm{~d}$ (sampling day plus $\left.2 \mathrm{~d}_{\text {before; }} \mu \mathrm{mol} \mathrm{m}{ }^{-2} \mathrm{~s}^{-1}\right)$ and chlorophyll a $\left(\mathrm{chl}_{\mathrm{i}} \mathrm{mg} \mathrm{m}^{-3}\right)$ distributions in the Ría de Vigo from 27 September to 8 October 1993

salinity and density in the Ría. Nitrate levels successively decreased (Fig. 3) possibly due to phytoplankton consumption. $E_{z}$ levels were highest, $>1000 \mu \mathrm{mol} \mathrm{m} \mathrm{m}^{-2}$ $\mathrm{s}^{-1}$ in the surface layer, during upwelling which correlated with the chl maximum (Fig. 3). $E_{z}$ was reduced after 9 July, which coincided with a change from northeasterly to northwesterly winds (Table 2) and some cloud cover. Note that the slight difference in the northerly wind speed between spring and summer causes different effects due to the degree of stratification in each period. During the summer, thermal stratification is stronger and higher wind speeds are necessary to produce the hydrographic conditions observed in spring. By comparison, upwellling inside the Ría can result from northeasterly winds which rapidly produces positive estuarine circulation due to the orientation of the Ría (Fig. 1).

The autumn period started with a relaxation event on 27 September due to low wind velocity (Table 2). From 29 September to 4 October there was a downwelling event which can be traced from the temperature and nitrate distributions (Fig. 4). Coastal water was introduced into the Ría (Table 2 and also Fermín et al. 1996) carrying high chl concentrations (Fig. 4). During the strong downwelling from 1 to 4 October, the chl was washed downwards and outwards from the Ría (Fermín et al. 1996). Upwelling occurred at the end of the sampling period from 6 to 8 October, which replenished surface nitrate. The low chl levels left by the previous downwelling resulted in low chl during the sub- sequent upwelling (Fig. 4). $E_{z}$ levels were the lowest of all the sampling periods and were caused by dense cloud cover during the downwelling event.

\section{Dominant species within the total phytoplankton and nanophytoplankton fractions}

Dominant species in the total and nanophytoplankton fractions are given in Table 3 . Net phytoplankton can be deduced from the difference between total and nanophytoplankton. The pelagic diatom Rhizosolenia delicatula dominated the initial spring upwelling and the net phytoplankton fraction. $R$. delicatula may be counted as nanophytoplankton when it lands lengthwise on the filter and as net phytoplankton if it lands sideways. At the end of the upwelling period small flagellates became dominant. During downwelling, at the highest $P_{m}^{B}$ depth, the most abundant species were Chaetoceros laciniosus, Chaetoceros curvisetus and Leptocylindrus danicus (net phytoplankton). During the new upwelling pulse, flagellates again dominated.

In summer, net phytoplankton dominated the entire sampling period with several Chaetoceros spp. (C. curvisetus, $C$. debilis, $C$. compressus and $C$. didymus) in abundance. The nanophytoplankton fraction by biovolume was of less importance, however, as stratification succeeded small diatoms (Skeletonoma costatum, Leptocylindrus minimus and Leptocylindrus danicus) dominated this fraction. 
Table 3. Dominant phytoplankton by biovolume for total phytoplankton and nanophytoplankton fractions at the water column depth with the highest maximum photosynthetic rate, $P_{m}^{B}$. Net phytoplankton species are deduced from differences between the total and nanophytoplankton fractions. $\mathrm{LN}=$ samples with very low cell numbers in the nanophytoplankton fraction

\begin{tabular}{|c|c|c|c|c|}
\hline Date (1993) & Total phytoplankton & Biovolume $\left(\mu \mathrm{m}^{3} \mathrm{I}^{-1}\right)$ & Nanophytoplankton & Biovolume $\left(\mu \mathrm{m}^{3} \mathrm{l}^{-1}\right)$ \\
\hline \multicolumn{5}{|l|}{ Spring } \\
\hline \multirow[t]{3}{*}{ Apr 14} & Rhizosolenia delicatula & 173 & Rhizosolenia delicatula & 32 \\
\hline & Chaetoceros curvisetus & 50 & Gymnodinium varians & 25 \\
\hline & Chaetoceros socialis & 20 & Cryptophycea & 18 \\
\hline \multirow[t]{3}{*}{ Apr 16} & Rhizosolenia delicatula & 56 & Small flagellates & 223 \\
\hline & Rhizosolenia setigera & 13 & Cryptophycea & 13 \\
\hline & Chaetoceros didymus & 6 & Rhizosolenia delicatula & 3 \\
\hline \multirow[t]{3}{*}{ Apr 19} & Rhizosolenia delicatula & 96 & Small flagellates & 156 \\
\hline & Chaetoceros curvisetus & 80 & Cryptophycea & 23 \\
\hline & Leptocylindrus danicus & 25 & Rhizosolenia delicatula & 4 \\
\hline \multirow[t]{3}{*}{ Apr 21} & Chaetoceros laciniosus & 223 & Sinall flagellates & 128 \\
\hline & Chaetoceros curvisetus & 102 & Cryptophycea & 11 \\
\hline & Chaetoceros dydimus & 38 & Leptocylindrus danicus & 5 \\
\hline \multirow[t]{3}{*}{ Apr 23} & Chaetoceros laciniosus & 12464 & Leptocylindrus danicus & 484 \\
\hline & Chaetoceros curvisetus & 6775 & Thalassiosira nana & 313 \\
\hline & Leptocylindrus danicus & 2469 & Small flagellates & 292 \\
\hline \multirow[t]{3}{*}{ Apr 27} & Small flagellates & 833 & Simall flagellates & 97 \\
\hline & Prorocentrum micans & 141 & Cryptophycea & 16 \\
\hline & Cryptophycea & 17 & Thalassiosira nana & 5 \\
\hline \multicolumn{5}{|l|}{ Summer } \\
\hline \multirow[t]{3}{*}{ Jul 5} & Chaetoceros curvisetus & 2306 & Small flagellates & 24 \\
\hline & Chaetoceros debilis & 796 & Cyanobacteria & 15 \\
\hline & Skeletonema costatum & 284 & Cryptophycea & 3 \\
\hline \multirow[t]{3}{*}{ Jul 7} & Chaetoceros debilis & 2012 & Skeletonema costatum & 244 \\
\hline & Chaetoceros curvisetus & 1540 & Small flagellates & 213 \\
\hline & Skeletonema costatum & 932 & Cryptophycea & 31 \\
\hline \multirow[t]{3}{*}{ Jul 9} & Chaetoceros curvisetus & 1242 & Small flagellates & 568 \\
\hline & Chaetoceros debilis & 446 & Cryptophycea & 26 \\
\hline & Skeletonema costatum & 205 & Cachonina niei & 2 \\
\hline \multirow[t]{3}{*}{ Jul 12} & Chaetoceros compressus & 670 & Leptocylindrus danicus & 532 \\
\hline & Chaetoceros curvisetus & 468 & Small flagellates & 52 \\
\hline & Chaetoceros debilis & 121 & Gymnodinium nanum & 3 \\
\hline \multirow[t]{3}{*}{ Jul 14} & Chaetoceros curvisetus & 499 & Leptocylindrus minimus & 118 \\
\hline & Leptocylindrus minimus & 130 & Small flagellates & 34 \\
\hline & Asterionella japonica & 94 & Gymnodinium hamulus & 10 \\
\hline \multirow[t]{3}{*}{ Jul 16} & Chaetoceros didymus & 315 & Leptocylindrus minimus & 277 \\
\hline & Leptocylindrus danicus & 218 & Small flagellates & 73 \\
\hline & Leptocylindrus minimus & 175 & Heterosigna akashiwo & 18 \\
\hline \multicolumn{5}{|l|}{ Autumn } \\
\hline \multirow[t]{3}{*}{ Sep 27} & Chaetoceros curvisetus & 2569 & Skeletonema costatum & 881 \\
\hline & Chaetoceros debilis & 520 & Small flagellates & 106 \\
\hline & Skeletonema costatum & 480 & Cryptophycea & 63 \\
\hline \multirow[t]{3}{*}{ Sep 29} & Skeletonema costatum & 896 & Skeletonema costatum & 338 \\
\hline & Chaetoceros debilis & 520 & Small flagellates & 227 \\
\hline & Small flagellates & 277 & Cryptophycea & 23 \\
\hline \multirow[t]{3}{*}{ Oct 1} & Gymnodinium catenatum & 346 & S. costatum & 654 \\
\hline & Chaetoceros socialis & 42 & Cachonina niei & 569 \\
\hline & Chaetoceros debilis & 31 & Small flagellates & 55 \\
\hline Oct 4 & Gymnodinium catenatum & 53 & $L N$ & \\
\hline & Chaetoceros socialis & 50 & $\mathrm{LN}$ & \\
\hline & Small flagellates & 46 & $\mathrm{LN}$ & \\
\hline Oct 6 & Gymnodinium catenatum & 66 & Small flagellates & 48 \\
\hline & Chaetoceros socialis & 35 & Cachonina niei & 7 \\
\hline & Pseudonitzschia cf. seriata & 24 & Gymnodinium nanum & 2 \\
\hline Oct 8 & Gymnodinium catenatum & 444 & Small flagellates & 256 \\
\hline & Pseudonitzschia cf. seriata & 319 & Mesodinium rubrum & 236 \\
\hline & Mesodinium rubrum & 301 & Cachonina niei & 6 \\
\hline
\end{tabular}


On the first sampling date of autumn, Chaetoceros curvisetus (net phytoplankton) and Skeletonema costatum (nanophytoplankton) accounted for the highest biovolume. S. costatum and small flagellates were important in both fractions during the initial downwelling. Further downwelling caused the total biovolume to be reduced and a clear change in the phytoplankton populations occurred with Gymnodinium catenatum (net phytoplankton) being dominant. A new upwelling pulse increased the biovolume of $G$. catenatum, Pseudonitzschia cf. seriata and the autotrophic ciliate Mesodinium rubrum. The nanophytoplankton fraction also responded to the upwelling pulse with an increase in biovolume.

\section{Photosynthetic parameters}

The range in $\alpha^{B}$ (Fig. 5) for the total phytoplankton was 0.006 to 0.058 , for the net phytoplankton 0.005 to 0.049 and for the nanophytoplankton, 0.005 to $0.066 \mathrm{mg} \mathrm{C}$ (mg chl $)^{-1} \mathrm{~h}^{-1}$ ( $\left.\mu \mathrm{mol} \mathrm{m}^{-2} \mathrm{~s}^{-1}\right)^{-1}$. Using pooled data from all of the 3 sampling periods, significant differences were found between net phytoplankton and nanophytoplankton for the light limited slope, $\alpha^{B}\left(F_{1,86}=13.07, \mathrm{p}<0.001\right)$, nanophytoplankton had the highest mean (Table 4 ). There were no significant differences in $\alpha^{B}$ between seasons for all size classes.

The range in $P_{m}^{B}$ was 0.61 to 7.27 for the total phytoplankton, 0.41 to 17.64 for the net phytoplankton and 0.57 to $9.17 \mathrm{mg} \mathrm{C}(\mathrm{mg} \mathrm{chl})^{-1} \mathrm{~h}^{-1}$ for the nanophytoplankton (Fig 6). There were no significant differences between $P_{m}^{B}$ of the net and nanophytoplankton and no significant differences in $P_{m}^{B}$ between seasons for both the total phytoplankton and the net phytoplankton (Table 4). There were significant differences in nanophytoplankton $P_{m}^{B}$ between seasons $\left(F_{2,43}=5.29, \mathrm{p}<\right.$ 0.009 ; Table 4$)$, with the highest value recorded in summer and lowest in spring (Table 4).

The principal component analysis (PCA) applied to photosynthetic and hydrographic variables (Table 5) explained $50 \%$ of the total variance. Principal component 1 (PC 1) explained $29 \%$ of the total variability and $\alpha^{B}$ for the total and nanophytoplankton was associated with $\mathrm{NO}_{3}$ and density. PC 1 also grouped $P_{m}^{B}$ of all fractions with temperature, irradiance and chl. PC 2 explained $21 \%$ of the variation and grouped $\alpha^{B}$ of all fractions and $P_{m}^{B}$ of the total and net phytoplankton with $\mathrm{NO}_{3}$.

\section{Primary production}

The range in water column primary production for the total phytoplankton in the Ría de Vigo during the 1993 sampling periods was 65 to $3690 \mathrm{mg} \mathrm{C} \mathrm{m}^{-2} \mathrm{~d}^{-1}$

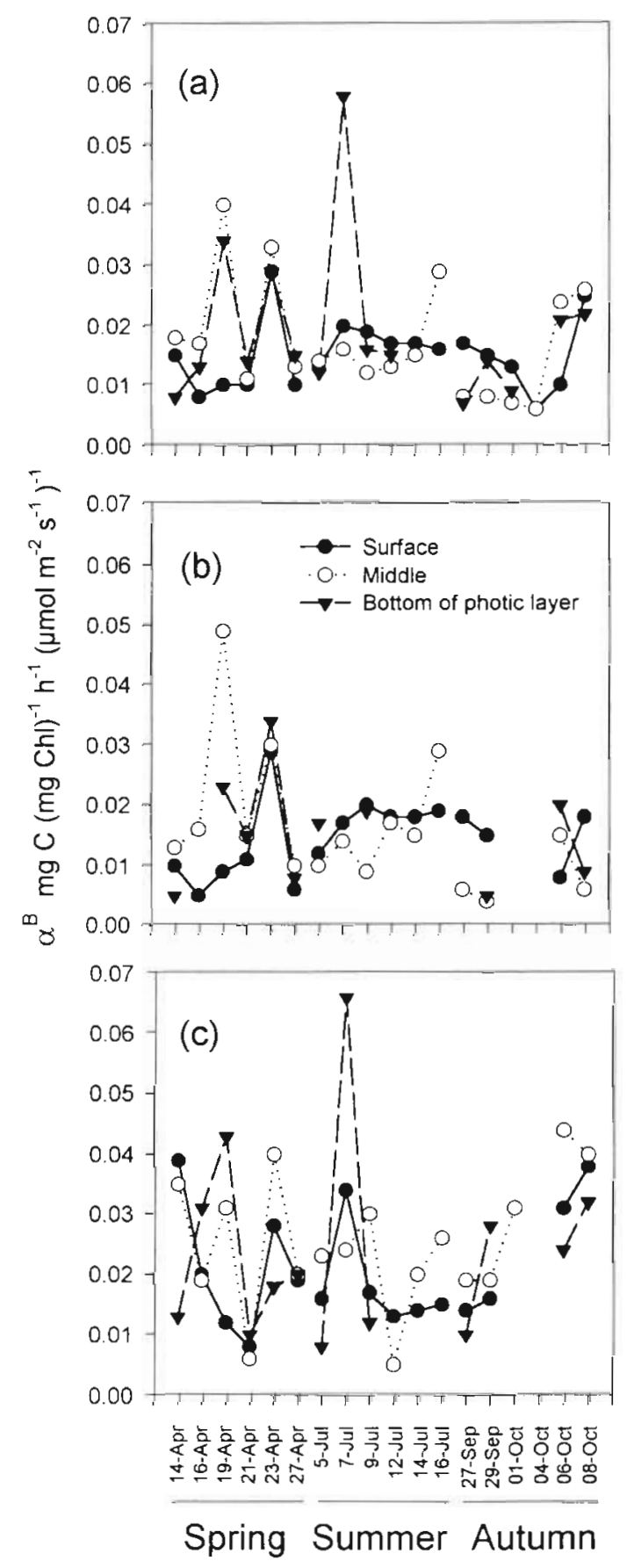

Fig. 5. Light limited slope, $\alpha^{B}$ for (a) the total phytoplankton (b) net phytoplankton and (c) nanophytoplankton during spring, summer and autumn 1993

$($ mean $=1394 \pm 1174$, Table 6$)$. Net phytoplankton primary production ranged from 65 to $2833 \mathrm{mg} \mathrm{C} \mathrm{m}^{-2} \mathrm{~d}^{-1}$ (mean $=954 \pm 847 ;$ Table 6$)$ and was significantly higher than that for nanophytoplankton $\left(F_{1.88}=4.74\right.$, $\mathrm{p}<0.005)$, constituting $66 \%$ of the mean upwelling season primary production. For the nanophytoplank- 
Table 4. Seasonal mean values and standard deviation of $\alpha^{B} \mathrm{mg} \mathrm{C}(\mathrm{mg} \mathrm{chl})^{-1} \mathrm{~h}^{-1}\left(\mu \mathrm{mol} \mathrm{m} \mathrm{m}^{-2} \mathrm{~s}^{-1}\right)^{-1}$ and $P_{\mathrm{m}}^{B} \mathrm{mg} \mathrm{C}(\mathrm{mg} \mathrm{chl})^{-1} \mathrm{~h}^{-1}$ for total, net and nanophytoplankton

\begin{tabular}{|llccc|}
\hline $\begin{array}{l}\text { Photosynthetic } \\
\text { parameter }\end{array}$ & Season & Total phytoplankton & Net phytoplankton & Nanophytoplankton \\
\hline$\alpha^{B}$ & & & & \\
& Spring & $0.018 \pm 0.010$ & $0.017 \pm 0.012$ & $0.023 \pm 0.011$ \\
& Summer & $0.019 \pm 0.011$ & $0.017 \pm 0.005$ & $0.022 \pm 0.014$ \\
& Auturnn & $0.014 \pm 0.007$ & $0.011 \pm 0.006$ & $0.027 \pm 0.010$ \\
$P_{m}^{B}$ & All seasons & $0.017 \pm 0.009$ & $0.015 \pm 0.008$ & $0.023 \pm 0.012$ \\
& Spring & $1.77 \pm 0.96$ & $1.68 \pm 1.07$ & $1.91 \pm 1.05$ \\
& Summer & $2.70 \pm 1.53$ & $3.17 \pm 4.24$ & $3.91 \pm 2.36$ \\
& Autumn & $2.08 \pm 0.87$ & $1.96 \pm 0.92$ & $3.54 \pm 1.30$ \\
& All seasons & $2.16 \pm 1.21$ & $2.25 \pm 2.57$ & $3.02 \pm 1.90$ \\
\hline
\end{tabular}

Table 5. Principal component analysis (PCA) of total, net and nanophytoplankton photosynthetic parameters $\left(\alpha^{B}\right.$ and $\left.P_{m}^{B}\right)$ with other environmental variables: temperature $\left({ }^{\circ} \mathrm{C}\right)$, salinity $(\mathrm{S})$, density $\left(\sigma_{t}\right)$, nitrates $\left(\mathrm{NO}_{3}\right)$, chlorophyll (chl) and irradiance $\left(E_{z}\right)$ in the Ría de Vigo. Variables are ordered according to their correlation with PC 1

\begin{tabular}{|lrr|}
\hline Variable & PC 1 & PC 2 \\
\hline${ }^{\circ} \mathrm{C}$ & 0.802 & 0.014 \\
$E_{z}$ & 0.787 & 0.037 \\
$\mathrm{Chl}$ & 0.723 & -0.170 \\
$P_{m}^{B}$ nano & 0.595 & 0.047 \\
$p_{m \text { total }}^{B}$ total & 0.569 & 0.658 \\
$P_{m}^{B}$ net & 0.543 & 0.587 \\
$\mathrm{~S}$ & 0.068 & -0.160 \\
$\alpha^{B}$ net & -0.066 & 0.570 \\
$\alpha^{B}$ nano & -0.204 & 0.631 \\
$\alpha^{B}$ total & -0.265 & 0.845 \\
$\mathrm{NO}_{3}$ & -0.502 & 0.436 \\
$\sigma_{1}$ & -0.597 & 0.032 \\
\hline
\end{tabular}

ton values of between 0 and $1650 \mathrm{mg} \mathrm{C} \mathrm{m}^{-2} \mathrm{~d}^{-1}$ were recorded $($ mean $=466 \pm 400$, Table 6$)$. When net phytoplankton production was low during strong downwelling conditions on 4 October, nanophytoplankton production was below the detection limit (Table 6).

Using primary production values for each depth in the water column, $P_{z}\left(\mathrm{mgC} \mathrm{m}^{-3} \mathrm{~d}^{-1}\right)$, rather than water column integrated values, significantly higher $P_{z}$ were recorded in summer for the total phytoplankton $\left(F_{2,46}=\right.$ 3.37, $p<0.043$ ). For the net phytoplankton, no significant differences were found in $P_{z}$ between seasons, but for nanophytoplankton, summer $P_{z}$ was significantly higher $\left(F_{2,41}=4.01, \mathrm{p}<0.026\right)$.

PCA applied to $P_{z}$ and hydrographic variables explained $81 \%$ of the total variance with 2 components. PC 1 explained $60 \%$ of the variation and segregated $P_{z}$ for all groups with temperature (Table 7). PC 2 accounted for $21 \%$ of the variation and segregated density and salinity with $P_{Z}$ for all groups.

\section{DISCUSSION}

The range in $P_{m}^{B}$ corresponded to the values of Kyewalyanga et al. (1998), to values found in other upwelling areas (González-Rodríguez 1994) and for other estuarine systems (Harding et al. 1985). The mean $\alpha^{B}$ for the total phytoplankton (Table 4 ) is similar to that recorded by Kyewalyanga et al. (1998) in spring and autumn for stations on the coastal boundary of the NW Atlantic continental shelf waters, NWCS (mean $0.012 \mathrm{mg} \mathrm{C}[\mathrm{mg} \mathrm{chl}]^{-1} \mathrm{~h}^{-1}\left[\mu \mathrm{mol} \mathrm{m} \mathrm{m}^{-2} \mathrm{~s}^{-1}\right]^{-1} \mathrm{cal}-$ culated without correction for tungsten lamps). The higher mean $\alpha^{B}$ of nanophytoplankton (Table 4 ) suggests that this size class have a higher light utilisation efficiency than net phytoplankton. Previous studies have reported similar differences in $\alpha^{B}$ between size class (Malone \& Neale 1981, Platt et al. 1993). Geider et al. (1986) showed that $\alpha^{B}$ decreases with increasing cell size and related this to faster growth rates for smaller cells. The difference between $\alpha^{B}$ of net and nanophytoplankton reported here may not only be related to size differences but also to species specific differences (Gallegos 1992). Small flagellates and small diatoms were abundant in the nanophytoplankton whereas Chaetoceros spp. were common in the net phytoplankton (Table 3 ). The co-segregation of $\alpha^{B}$ for the total and nanophytoplankton with $\mathrm{NO}_{3}$ and density by $\mathrm{PC} 1$ (Table 5) indicates that upwelling augments nanophytoplankton $\alpha^{B}$ especially in the surface and middle layers (Fig. 5) and is an immediate photosynthetic response by nanophytoplankton to upwelling. By comparison, PC2 co-segregated $P_{m}^{B}$ of net and total phytoplankton and $\alpha^{B}$ of all fractions with $\mathrm{NO}_{3}$ and illustrates the subsequent response of net phytoplankton to the upwelling event. These differences in PCA correlations and the co-variation of nanophytoplankton $P_{z}$ with salinity, density and total $P_{z}$ (PC2, Table 7) also demonstrates that nanophytoplankton respond photosynthetically to upwelling before net phytoplankton. This suggests that when 

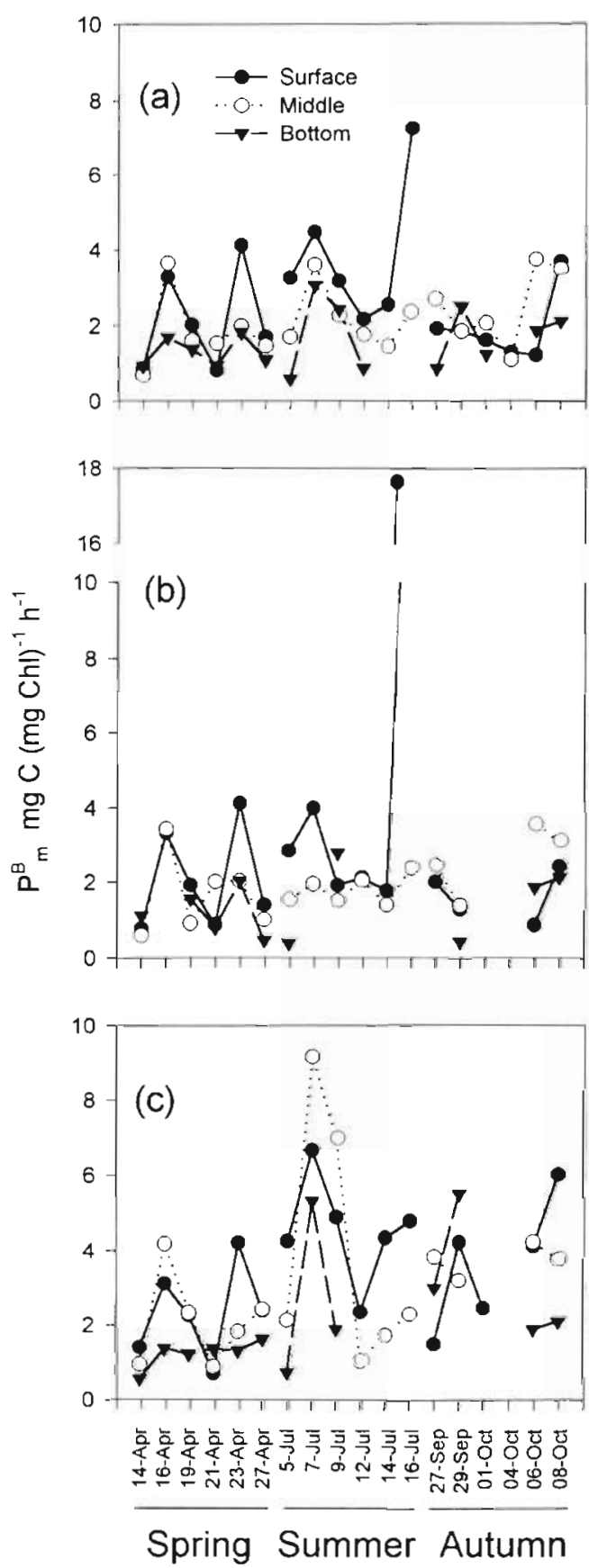

Fig. 6. Maximum photosynthetic rate, $P_{m}^{B}$, for (a) total phytoplankton (b) net phytoplankton and (c) nanophytoplankton during spring, summer and autumn 1993

both nano and net phytoplankton are moved into the photic zone during upwelling, nanophytoplankton respond to the sudden increase in irradiance before the net phytoplankton.

The fact that no significant differences were found in net phytoplankton $P_{z}$ between seasons but that there were significant differences in nanophytoplankton $P_{z}$ implies that most of the variation in primary production in the Ría is due to nanophytoplankton. This is further supported by the fact that nanophytoplankton had a significantly higher $\alpha^{B}$ than net phytoplankton and there were significant differences in nanophytoplankton $P_{m}^{B}$ between seasons. By comparison, no difference in net phytoplankton $\alpha^{B}$ and $P_{m}^{B}$ were found between seasons. The co-variation of total and nanophytoplankton $P_{z}$ with salinity and density (PC2 Table 7 ) and not such clear co-variation with net phytoplankton $P_{z}$ also illustrates that variations in nanophytoplankton primary production cause the variation in total phytoplankton primary production. Upwelling/downwelling cycles therefore are responsible for larger variations in nanophytoplankton primary production than in net phytoplankton. This is in contrast to the scenario of the open ocean (Goldman 1993) and some embayments (Malone 1971), where net phytoplankton cause the variation in primary production and nanophytoplankton primary production remains stable.

The range in water column primary production for the Ría de Vigo during the upwelling season in 1993 (Table 6) was higher than the values reported by Bode et al. (1993) for this region during spring and summer 1984 and 1985 (500 to $1330 \mathrm{mg} \mathrm{C} \mathrm{m}^{-2} \mathrm{~d}^{-1}$ converted from $\mathrm{mg} \mathrm{C} \mathrm{m} \mathrm{m}^{-2} \mathrm{~h}^{-1}$ using an average of $12 \mathrm{~h}$ daylight). By comparison with other upwelling systems, primary production in the Ría de Vigo is similar to that in the Benguela which has a range of 500 to $4000 \mathrm{mg} \mathrm{C} \mathrm{m}^{-2}$ $\mathrm{d}^{-1}$ (Shannon \& Field 1985, Brown \& Field 1986, Estrada \& Marrasé 1987, Brown et al. 1991), the Peruvian upwelling system (1894 $\mathrm{mg} \mathrm{C} \mathrm{m}^{-2} \mathrm{~d}^{-1}$; Barber \& Smith 1981), the Chilean (3000 $\mathrm{mg} \mathrm{C} \mathrm{m}^{-2} \mathrm{~d}^{-1}$; Marin et al. 1993, Montecino et al. 1996), Monterey Bay and the Californian system (500 to $2600 \mathrm{mg} \mathrm{C} \mathrm{m}^{-2} \mathrm{~d}^{-1}$; Pilskaln et al. 1996) and other estuarine ecosystems (100 to $2500 \mathrm{mg} \mathrm{C} \mathrm{m}^{-2} \mathrm{~d}^{-1}$; Boyton et al. 1982). In the Ría there was higher water column primary production in summer for the total phytoplankton, which must be related to the higher light regime, temperature and $P_{m}^{B}$ values and no nutrient limitation due to upwelling (Fraga et al. 1992).

The study of primary production as a function of size class is important in understanding the energy pathways and carbon availability in the pelagic food web (Williams 1981). Generally, nanophytoplankton pass into the microbial loop (Azam et al. 1983) and net phytoplankton go directly into the classic, short, food chain (Cushing 1989). Net phytoplankton was dominant in the Ría throughout the upwelling season (Table 3 ) and contributes $66 \%$ of the mean Ría primary production (Table 6). By comparison, in the Benguela upwelling it contributes $42 \%$ of the total primary production (Painting et al. 1993). The fact that net phytoplankton contribute more to the primary production of the Ría de Vigo than the nanophytoplankton evidently 
Table 6. Daily integrated primary production $\left(\mathrm{mg} \mathrm{C} \mathrm{m}^{-2} \mathrm{~d}^{-1}\right)$ in the photic layer of $\operatorname{Stn} 3$ in the Ria de Vigo during spring, summer and autumn 1993. BD = below detection limits; the mean of each sampling period is given in bold

\begin{tabular}{|c|c|c|c|c|}
\hline Date (1993) & Upwelling/downwelling event & Total phytoplankton & Net phytoplankton & Nanophytoplankton \\
\hline Apr 14 & Upwelling & 357.77 & 251.79 & 105.98 \\
\hline Apr 16 & Upwelling & 984.92 & 691.83 & 293.09 \\
\hline Apr 19 & Downwelling & 746.21 & 488.89 & 257.32 \\
\hline Apr 21 & Downwelling & 466.93 & 344.34 & 122.59 \\
\hline Apr 23 & Relaxation & 3319.18 & 2619.34 & 699.84 \\
\hline Apr 27 & Upwelling & 350.74 & 156.94 & 193.8 \\
\hline Mean & & 1037.63 & 758.85 & 278.76 \\
\hline Jul 5 & Upwelling & 2779.44 & 1737.32 & 1042.12 \\
\hline Jul 7 & Upwelling & 3689.93 & 2833.26 & 856.67 \\
\hline Jul 9 & Relaxation & 1612.63 & 934.92 & 677.71 \\
\hline Jul 12 & Stratification & 1394.43 & 1183.44 & 210.99 \\
\hline Jul 14 & Stratification & 1074.63 & 668.33 & 406.3 \\
\hline Jul 16 & Stratification & 3563.64 & 1913.07 & 1650.57 \\
\hline Mean & & 2352.45 & 1545.06 & 807.38 \\
\hline Sep 27 & Stratification & 2283.98 & 1865.30 & 418.68 \\
\hline Sep 29 & Downwelling & 1069.64 & 599.84 & 469.8 \\
\hline Oct 1 & Downwelling & 446.87 & 356.15 & 90.72 \\
\hline Oct 4 & Downwelling & 65.16 & 65.16 & $\mathrm{BD}$ \\
\hline Oct 6 & Upwelling & 522.01 & 321.35 & 200.66 \\
\hline Oct 8 & Upwelling & 367.80 & 137.19 & 230.61 \\
\hline Mean & & 792.57 & 510.47 & 282.09 \\
\hline
\end{tabular}

Table 7. Principal component analysis (PCA) of $P_{p}$ for the total, net and nanophytoplankton with temperature $\left({ }^{\circ} \mathrm{C}\right)$, salinity (S), density $\left(\sigma_{1}\right)$, nitrates $\left(\mathrm{NO}_{3}\right)$ in the Ría de Vigo. Variables are ordered according to their correlation with PC1

\begin{tabular}{|lrr|}
\hline$P_{z}$ & PC1 & PC2 \\
\hline $\mathrm{NO}_{3}$ & 0.797 & 0.206 \\
$\sigma_{1}$ & 0.726 & -0.684 \\
$\mathrm{~S}$ & 0.536 & -0.805 \\
${ }^{\circ} \mathrm{C}$ & -0.734 & 0.024 \\
$P_{z}$ nano & -0.831 & -0.394 \\
$P_{z}$ total & -0.879 & -0.346 \\
$P_{z}$ net & -0.879 & -0.169 \\
\hline
\end{tabular}

influences the high productivity of shellfish and fish by direct energy transfer through the classic, short, mesozooplankton food chain. This potentially results in a high export of biomass and particulate matter to the shelf (Álvarez-Salgado et al. 1996. Doval et al. 1997). For the nanophytoplankton, the average contribution to daily integrated primary production in the Ria de Vigo was $34 \%$, in contrast to other oceanic regions of the NE Atlantic where it can be as much as $50 \%$ (Joint et al. 1993).

Primary production should be high during weak upwelling since the outflow of Ría water is low and the phytoplankton remains in the photic zone for a prolonged period (Figueiras \& Pazos 1991, ÁlvarezSalgado et al. 1996). Downwelling blocks the positive
Ría circulation and causes an accumulation of phytoplankton situated in the Ría interior (Tilstone et al. 1994). Phytoplankton situated in the middle of the Ría can move downwards into a lower light regime and outwards through bottom waters (Figueiras et al. 1994). The primary production of phytoplankton situated in the Ría interior may therefore increase, whereas that of phytoplankton in the middle of the Ría decreases. In the present study, the lowest primary production was found during the autumn downwelling, whereas the highest was found during the transition from upwelling to upwelling relaxation and stratification in summer and during downwelling relaxation in spring (Table 6). This contrasts a number of studies that predict low production during stratification (Prestidge \& Taylor 1995, Ménesguen \& Hoch 1997) and high production during high water mixing (Cullen \& Lewis 1988). However, our results support Légendre's (1981) stabilisation/destabilisation theory and agree with Nelson's observations (1992) that the periodicity of wind causing upwelling is more important in determining production than its integrated strength and duration. They also complement numerous other studies that have stressed the importance of periodic relaxation and stratification events in enhancing primary production (reviewed by Mann 1993). Species differences (Côté \& Platt 1984, Gallegos 1992) also evidently contribute to the high primary production of the Ría. The highest values coincided with Chaetoceros spp. and the lowest with dinoflagellates 
such as Gymnodinium catenatum. Size class, species and upwelling/downwelling followed by relaxation therefore contribute to high primary production events in the Ría.

\section{CONCLUSIONS}

In the Ría de Vigo during the upwelling season net phytoplankton primary production is high and relatively stable and the classic food chain is therefore dominant. Size class, species and upwelling/downwelling followed by relaxation contribute to high primary production events in the Ría. nanophytoplankton primary production is lower than that of net phytoplankton but nanophytoplankton cause the variation in primary production. The data suggest that more carbon is circulated in the microbial loop during the initial phase of upwelling and more carbon is directly available through the shorter, mesozooplankton food chain during subsequent stages of upwelling and stratification and during downwelling less carbon is circulated through both systems. It is concluded that upwellingdownwelling cycles cause a larger variation in energy transfer through the microbial loop than through the short, food chain in the Ría, which is principally due to the co-variation of $\alpha_{<20 \mu m}^{B}$ with $\mathrm{NO}_{3}$ caused by upwelling pulses

Acknowledgements. We are grateful to the members of the oceanography team at the Instituto de Investigacións Marinas, Vigo, who participated in the sampling and analysis of hydrographic parameters and particularly X. A. Álvarez-Salgado for nutrient analysis. This work was financed partly by the Xunta de Galicia (project Xuga 40205 B 92) and by the Comisión Interministerial de Ciencia y Tecnología (CICYT; project AMB92-0165). B.A. was funded by a post graduate grant from the Xunta de Galicia. E.G.F. was supported by the Plan de Formación de Recursos Humanos of the Oriente University, Venezuela and G.H.T by the European Commission MAST programme (MAS3-CT96-5022).

\section{LITERATURE CITED}

Álvarez-Salgado XA, Rosón G, Pérez FF, Pazos Y (1993) Hydrographic variability off the Rías Baixas (NW Spain) during the upwelling season. J Geophys Res 98(C8): $14447-14455$

Álvarez-Salgado XA, Rosón G, Pérez FF, Figueiras FG, Pazos $Y(1996)$ Nitrogen cycling in an estuarine upwelling system, the Ría de Arousa (NW Spain). 1: Short-time-scale patterns of hydrodynamic and biogeochemical circulation. Mar Ecol Prog Ser 135:259-273

Azam F (1998) Microbial control of oceanic carbon flux: the plot thickens. Science 280:694-696

A.zam F, Fenchel T, Field JG, Gray JS, Meyer-Reil LA, Thingstad $F$ (1983) The ecological role of water-column microbes in the sea. Mar Ecol Prog Ser 10:257-263
Bakun A (1973) Coastal upwelling indices, west coast of North America, 1946-71. NOAA Tech Rep NMFS SSRF 671. US Dept of Commerce, Seattle

Banse K (1976) Rates of growth, respiration and photosynthesis of unicellular algae as related to cell size-a review. J Phycol 12:135-140

Barber RT, Smith RL (1981) Coastal upwelling ecosystems. In: Longhurst AR (ed) Analysis of marine ecosystems. Academic Press, New York, p 31-68

Bode A, Casas B, Fernández E, Marañón E, Serret P, Varela M (1993) Variability of phytoplankton biomass and primary productivity in the shelf waters of the upwelling area of $\mathrm{N}$ NW Spain. ICES. L 53:1-10

Bode A, Casas B, Varela M (1994) Size fractionated primary productivity and biomass in the Galician shelf (NW Spain): net-phytoplankton yersus nano-phytoplankton dominance. Sci Mar 58:131-141

Boyton WR, Kemp WM, Keefe CW (1982) A comparative analysis of nutrients and other factors influencing estuarine phytoplankton production. In: Kennedy VS (ed) Estuarine comparisons. Academic Press, New York, p 69-90

Brown PC, Field JG (1986) Factors limiting phytoplankton production in a nearshore upwelling area. J Plankton Res 8:55-68

Brown PC, Painting SJ, Cochraine KL (1991) Estimates of phytoplankton and bacterial biomass and production in the northern and southern Benguela ecosystems. S Afr J Mar Sci 11:537-564

Côté B, Platt T (1984) Utility of the light-saturation curve as an operational model for quantifying the effects of environmental conditions on phytoplankton photosynthesis. Mar Ecol Prog Ser 18:57-66

Cullen JC, Lewis MR (1988) The kinetics of algal photoadaptation in the context of vertical mixing. J Plankton Res 10: $1039-1063$

Cushing DH (1989) A difference in structure between ecosystems in strongly stratified waters and in those that are only weakly stratified. J Plankton Res 11:1-13

Doval MD, Álvarez-Salgado XA, Pérez FP (1997) Dissolved organic matter in a temperate embayment affected by coastal upwelling. Mar Ecol Prog Ser 157:21-37

Edler L (1979) Recommendations for marine biological studies in the Baltic Sea. Phytoplankton and chlorophyll. Balt Mar Biol 5:1-38

Estrada M, Marrasé C (1987) Phytoplankton biomass and productivity off the Namibian coast. In: Payne AIL, Gulland JA, Brink KH (eds) The Benguela and comparable ecosystems. S Afr J Mar Sci 5:347-356

Falkowski PG (1981) Light-shade adaptation and assimilation numbers. J Plankton Res 3:203-216

Fermín EG, Figueiras FG, Arbones B, Villarino ML (1996) Short-time scale development of a Gymnodinium catenatum population in the Ría de Vigo (NW Spain). J Phycol 32: 212-221

Figueiras FG, Pazos X (1991) Microplankton assemblages in three Rías Baixas (Vigo, Arosa and Muros, Spain) with a subsurface chlorophyll maximum: their relationship to hydrography. Mar Ecol Prog Ser 76:219-233

Figueiras FG, Jones KJ, Mosquera AM, Álvarez-Salgado XA, Edwards A, MacDougall N (1994) Red tide assemblage formation in an estuarine upwelling ecosystem: Ría de Vigo. J Plankton Res 16:857-878

Fraga F (1976) Fotosíntesis en la Ría de Vigo. Invest Pesq 40 151-167

Fraga F, Margalef R (1979) Las rías gallegas. In: Estudio y explotación del mar en Galicia. Cursos y congresos, University of Santiago, Santiago, p 101-121 
Fraga F, Pérez FF, Figueiras FG, Rios AF (1.992) Stoichiometric variations of $N_{1}, P, C$ and $\mathrm{O}_{2}$ during a Gymnodinium catenatum red tide and their interpretation. Mar Ecol Prog Ser 87:123-134

Gallegos CL (1992) Phytoplankton photosynthesis, productivity and species composition in a eutrophic estuary: comparison of bloom and non-bloom assemblages. Mar Ecol Prog Ser 81:257-267

Gallegos CL, Platt T, Harrison WG, Irwin B (1983) Photosynthetic parameters of arctic marine phytoplankton: vertical variations and time scales of adaptation. Limnol Oceanogr 28:698-708

Geider RJ, Platt T, Raven JA (1986) Size dependence of growth and photosynthesis in diatoms: a synthesis. Mar Ecol Prog Ser 30:93-104

Goldman JC (1993) Potential role of large oceanic diatoms in new production. Deep-Sea Res 40:159-168

Gonzalez-Rodriguez E (1994) Yearly variation in primary productivity of marine phytoplankton from Cabo Frio (RJ, Brazil) region. Hydrobiologia 294:145-156

Gonzalez-Rodriguez E, Valentin JL, André DL, Jacob SA (1992) Upwelling and downwelling at Cabo Frio (Brazil): comparison of biomass and primary production responses. J Plankton Res 14:289-306

Harding LW Jr, Meeson BW, Fisher TR Jr (1985) Photosynthesis patterns in Chesapeake Bay phytoplankton: short- and long-term responses of P-I curve parameters to light. Mar Ecol Prog Ser 26:99-111

Harding LW Jr, Meeson BW, Fisher TR Jr (1986) Phytoplankton production in two east coast estuaries: photosynthesis-light functions and patterns of carbon assimilation in Chesapeake and Delware Bays. Estuar Coast Shelf Sci 23:773-806

Harrison WG, Platt $T$ (1980) Variations in the assimilation number of coastal marine phytoplankton: effects of environmental covariates. J Plankton Res 2:249-260

Hood RR, Neuer S, Cowles TJ (1992) Autotrophic production, biomass and species composition at two stations across an upwelling front. Mar Ecol Prog Ser 83:221-232

Huntsman SA, Barber RT (1977) Primary production off Northwest Africa: the relationship to wind and nutrient conditions. Deep-Sea Res 24(1 A) :25-33

Joint I, Pomroy A, Savidge G, Boyd P (1993) Size-fractionated primary productivity in the northeast Atlantic in May-July 1989. Deep-Sea Res 40:423-440

Kiørboe T (1993) Turbulence, phytoplankton cell size and the structure of pelagic food webs. Adv Mar Biol 29:1-61

Kiørboe T, Kaas H, Kruse B, Mohlenberg F, Tiselius P, Aerteberg $G$ (1990) The structure of the pelagic food web in relation to water column structure in the Skagerrak. Mar Ecol Prog Ser 59:19-32

Kyewalyanga MN, Platt T, Sathyendranath S, Lutz VA, Stuart $V$ (1998) Seasonal variations in physiological parameters of phytoplankton across the North Atlantic. J Plankton Res 20:17-42

Légendre L (1981) Hydrodynamic control of marine phytoplankton production: the paradox of stability. In: Nihoul JCJ (ed) Ecohydrodynamics. Elsevier Oceanography Series, Elsevier, New York, p 191-208

Lewis MR, Horne EPW, Cullen JJ, Oakey NS, Platt T (1984) Turbulent motions may control phytoplankton photosynthesis in the upper ocean. Nature 311:49-50

Lohrenz SE, Fahnenstiel GL, Redalje DG (1994) Spatial and temporal cariations of photosynthetic parameters in relation to environmental conditions in coastal waters of the Northern Gulf of Mexico. Estuaries 17:779-795

Malone TC (1971) The relative importance of nano-phytoplankton and net-phytoplankton as primary producers in the Californian current system. Fish Bull US 69:799-820

Malone (1980) Size fractionated primary productivity of marine phytoplankton. In: Falkowski PG (ed) Primary productivity in the sea. Plenum Press, New York, p 301-319

Malone TC, Neale PJ (1981) Parameters of light-dependent photosynthesis for phytoplankton size fractions in temperate estuarine and coastal environments. Mar Biol 61 . 289-297

Mann KH (1993) Physical oceanography, food chains, and fish stocks: a review. ICES J Mar Sci 50:105-119

Marin V, Rodriguez L, Vallejo L, Fuenteseca J, Oyarce E (1993) Effects of coastal upwelling on the spring primary productivity of Mejillones del Sur Bay (Antofagasta Chile) Rev Chil Hist Nat 66:479-491

Marra J (1980) Phytoplankton photosynthetic response to vertical movement in a mixed layer. Mar Biol 46:203-208

McClain CR, Chao SY, Atkinson LP, Blanton JO, de Castillejo FF (1986) Wind driven upwelling in the vicinity of Cape Finisterre, Spain. J Geophys Res 91(C7):8470-8486

Ménesguen A, Hoch T (1997) Modelling the biogeochemical cycles of elements limiting primary production in the English Channel. I. Role of thermohaline stratification. Mar Ecol Prog Ser 146:173-188

Minas HJ, Packard TT, Minas M, Csote B (1982) An analysis of the production-regeneration system in the coastal upwelling area off NW Africa based on oxygen, nitrate, and ammonium distributions. J Mar Res 40:615-641

Moncoiffé G, Savidge G, Álvarez-Salgado XA, Figueiras FG (1993) Variability of surface planktonic community metabolism in response to coastal upwelling events in the Ria de Vigo (NW Spain). ICES council meeting papers, ICES, Copenhagen, L 32:1-16

Montecino V, Pizarro G, Quiroz D (1996) Phytoplankton dynamics in the upwelling-system off Coquimbo (30 degrees S) through the functional relationship between photosynthesis and irradiance (P-I). Gayana Oceanol 4: $139-151$

Mouriño C, Fraga F (1985) Determinación de nitratos en agua de mar. Invest Pesq 49:81-6

Nelson G (1992) Equatorward wind and atmospheric pressure spectra as metrics for primary productivity in the Benguela system. In: Payne AIL, Gulland JA, Brink $\mathrm{KH}$ (eds) The Benguela and comparable ecosystems. S Afr J Mar Sci 12: $19-28$

Nogueira E, Pérez FF, Rios AF (1997) Seasonal patterns and long term trends in an estuarine upwelling ecosystem (Ría de Vigo, NW Spain). Estuar Coast Shelf Sci 44:285-300

Painting SJ, Moloney CL, Lucas MI (1993) Simulation and field measurements of phytoplankton-bacteria-zooplankton interactions in the southern Benguela upwelling region. Mar Ecol Prog Ser 100:55-69

Peterson WT, Arcos DF, McManus GB, Dam H, Bellantoni D, Johnson T, Tiselius $P$ (1988) The nearshore zone during coastal upwelling: daily variability and coupling between primary and secondary production off Central Chile. Prog Oceanogr 20:1-40

Pilskaln CH, Paduan JB, Chavez FP, Anderson RY, Berelson WM (1996) Carbon export and regeneration in the coastal upwelling system of Monterey Bay, central California. J Mar Res 54:1149-1178

Platt T, Jassby AD (1976) The relationship between photosynthesis and light for natural assemblages of coastal marine phytoplankton. J Phycol 12:421-430

Platt T, Sathyendranath S, Ulloa O, Harrison WG, Hoepffner N, Goes J (1992) Nutrient control of phytoplankton photosynthesis in the western North Atlantic. Nature 356:229-331

Platt T, Sathyendranath S, Joint I, Fasham MJR (1993) Photo- 
synthetic characteristics of the phytoplankton in the Celtic sea during late spring. Fish Oceanogr 2:191-201

Prego R (1993) General aspects of carbon biogeochemistry in the Riá de Vigo, northwestern Spain. Geochem Cosmochim Acta 57:2041-2052

Prestidge MC, Taylor AH (1995) A modelling investigation of the distribution of stratification and phytoplankton abundance in the Irish Sea. J Plankton Res 17:1397-1420

Raven JA (1995) Scaling the seas. Plant Cell Environ 18: $1090-1100$

Ryther JH (1969) Photosynthesis and fish production in the sea. Science 33:149-163

Sathyendranath S, Longhurst A, Caverhill CM, Platt T (1995) Regionally and seasonally differentiated primary production in the North Atlantic. Deep-Sea Res 42:1773-1802

Semina HJ (1968) Water movement and the size of phytoplankton cells. Sarsia 34:267-272

Shannon LV, Field JG (1985) Are fish stocks food-limited in the southern Benguela pelagic ecosystem? Mar Ecol Prog Ser 22:7-19

Small LF, Menzies DW (1981) Patterns of primary productivity and biomass in a coastal upwelling region. Deep-Sea Res 28A: $123-149$

Tenore KR and 18 others (1995) Fisheries and oceanography off Galicia, NW Spain: mesoscale spatial and temporal

Editorial responsibility: Otto Kinne (Editor),

Oldendorf/Luhe, Germany changes in physical processes and resultant patterns biological productivity. J Geophys Res 100:10943-10966

Tilstone GH, Figueiras FG, Fraga F (1994) Upwelling/downwelling sequences in the generation of red tides in a coastal upwelling system. Mar Ecol Prog Ser 112: $241-253$

UNESCO (1983) Algorithms for computation of fundamental properties of seawater. UNESCO Tech Paper on Mar Sci $44: 1-53$

UNESCO (1985) The International system of units (SI) in Oceanography. UNESCO Tech Paper on Mar Sci 45:1-24

Utermöhl H (1958) Zur Vervollkommnung der quantitativen Phytoplankton-Methodik. Mitt Int Verein Theor Angew Limnol 9:1-38

Webb WL, Newton M, Starr D (1974) Carbon dioxide exchange of Alnus rubra; a mathematical model. Oecologia 17:281-291

Williams PJ le B (1981) Incorporation of microheterotrophic processes into the classic paradigm of the planktonic food web. Kieler Meeresforsch Sonderh 5:1-28

Yentsch CS, Menzel DW (1963) A method for the determination of phytoplankton chlorophyll and phaeophytin by fluorescence. Deep-Sea Res 10:221-231

Yoder JA, Ackleson SG, Barber RT, Flament P, Balch WM (1994) A line in the sea. Nature 371:689-692

Submitted: April 24, 1998; Accepted: March 2, 1999

Proofs received from author(s): June 28, 1999 